MATEC Web of Conferences 34, 02003 (2015)

DOI: $10.1051 /$ matecconf/ 20153402003

(C) Owned by the authors, published by EDP Sciences, 2015

\title{
A rotary drum screen with internal screw flights for Eri silkworm pupae
}

\author{
Kiattisin Kanjanawanishkul ${ }^{1, a}$, Pongsatorn Srinuan-on ${ }^{2}$, Pirawan Thammakit ${ }^{3}$ and Jakrachai Chinnakotr ${ }^{4}$ \\ 1,2,3,4 Mechatronics Research Unit, Faculty of Engineering, Mahasarakham University \\ ${ }^{1}$ Silk Innovation Center, Mahasarakham University \\ Kamriang, Kantharawichai, Mahasarakham, 44150, Thailand
}

\begin{abstract}
Eri silkworm pupae (Samia ricini) are very interesting creatures since they can be developed as a sustainable high protein food source for human beings and animals, and their cocoons can be used for silk production. At present, Thai silk is very famous for its special qualities, whereas the requirement of pupae as food grows increasingly, in particular, canned pupae with seasoning favors. Like other food products, size uniformity is required. Therefore, in this paper, a rotary drum screen with internal screw flights was designed and constructed for separating Eri silkworm pupae into two groups with different sizes. The experiments were conducted to evaluate its effectiveness. The results show that the optimal angular speed of the screen was $20 \mathrm{rpm}$ and the screw pitch value was $10 \mathrm{~cm}$. These parameters resulted in the accuracy percentage of pupa screening of $94.3 \%$ and the working capacity of $8.6 \mathrm{~kg} / \mathrm{h}$.
\end{abstract}

\section{Introduction}

An Eri silkworm pupa (Samia ricini) becomes a new interesting creature that can be developed as a sustainable high protein food source [1]. To make Eri silkworm pupae as commercial food products, one of the most common food preservation is to make canned Eri silkworm pupae [2]. Two important processing steps in making canned Eri silkworm pupae [2] include frying and drying. The silkworm pupae are fried to increase crispness, reduce the moisture and water activity. Then fried silkworms pupae are dried by a hot air oven. The rate of heat transfer for frying and drying is determined by the size of the individual pupa and thus variation in size would cause over-processing or under-processing. Additionally, size uniformity is important due to consumers' preference. Therefore, to maintain uniform size of pupae, screening is an essential operation. The screening results will ease time setting for frying and drying processes. At present, frozen pupae are manually sorted according to their size. This operation is very timeconsuming, laborious and non-consistent. Thus, the aim of this research project is to design and construct a drum screen that can separate undersized pupae from pupae with acceptable size. It can save time and cost. The need for workers is also decreased.

Since there is no product quality standard for Eri silkworm pupae, the size which is acceptable is ambiguous. Based on the experience of the canned-pupa manufacturer, the pupae with thickness less than $9.5 \mathrm{~mm}$ are considered undersized pupae, as shown in Figure 1a, whereas Figure $1 \mathrm{~b}$ shows pupae with acceptable size.
Thus, the thickness of pupae has been used to design the screen opening area of the drum screen.

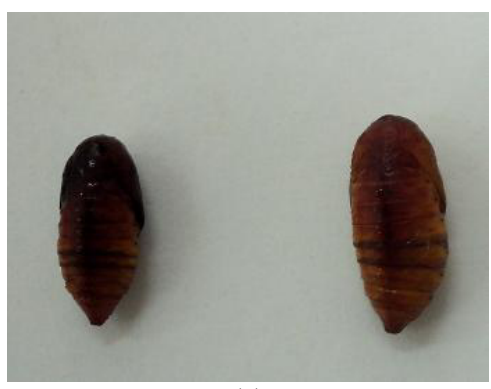

(a)

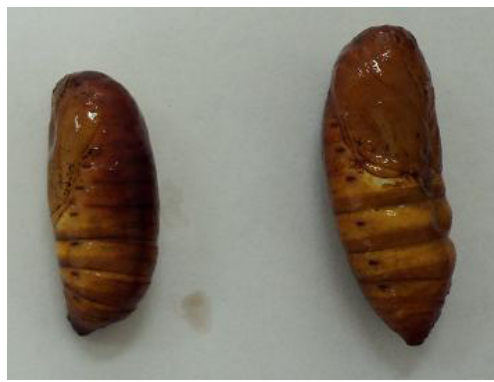

(b)

Figure 1. Pupae with different size: (a) undersized pupae and (b) acceptable pupae.

\section{Related work}

In the literature, many types of sorting/grading machines have been developed $[3,4]$. They are proven that they

\footnotetext{
a Corresponding author: kiattisin.k@msu.ac.th
} 
have contributed to increasing the market value of products and producing uniform products. Also, they can operate much faster than human workers. Thus, they are increasingly used to replace human workers. In general, sorting/grading machines can be divided into two techniques, i.e., mechanical sorting/grading and visonbased sorting/grading. The former is much cheaper and operate much faster, while the latter is more flexible. In this work, we focus on mechanical sorting/grading techniques.

Ghanbarian et al. [5] developed a potato-grading machine based on rotating drum. Design parameters included net stiffness, rotating drum speed and feeding rate. Golpira and Golpira [6] developed an apple sorting machine based on apple weights. Peak signal to noise ratio (PSNR) criterion was employed to analyze machine performance which helps its improvement. Gamea et al. [7] constructed a prototype of an orange grading machine based on dimensions. Kopral et al. [8] investigated classification of tomato seeds using a drum screen. It can separate seeds into fractions in a term of their size. Treeamnuk et al. [9] constructed and evaluated a sizing machine for java apple. Design criteria included sizing parameters which were determined by the diameter of the fruit and a sizing mechanism which caused minimum damage. Jarimopas et al. [10] developed a prototype of guava sizing machine. Later, they [11] developed a rotating disk mangosteen sizing machine.

Although there have been a large number of research papers related to screening machines based on a rotary drum screen, there is no screening machine for Eri silkworm pupae in the literature. This problem is very challenging since pupae can be deformed and easily damaged.

\section{Design and construction of a rotary drum screen with screw flights}

The main idea is to use screening which is performed by separating undersized pupae from pupae whose size is acceptable for making canned pupae. In the literature, there are many screening techniques. A drum screen equipped with bars is one of them. As illustrated in Figure $2 \mathrm{a}$, our drum screen consists of a cylindrical hollow drum (No. 1) with $0.4 \mathrm{~m}$ in diameter and $1.3 \mathrm{~m}$ in length. The internal spiral screw (No. 2) is used to transport pupae through the drum. The pitch of a screw is equal to $20 \mathrm{~cm}$. The drum rotates by drive belts (No. 3) and is driven by a 1-hp, $1440 \mathrm{rpm}$ AC motor (No. 4). It is equipped with bar screens consisting of parallel metal bars with $9.5 \mathrm{~mm}$ clear openings. When the drum is rotating about its horizontal axis, incoming pupae are fed into the drum through an inlet hopper (No. 5). During passing through the drum, undersized pupae will fall through screen openings between bars and are collected in the trough (No. 6) underneath, while acceptable pupae will remain in the drum and are brought towards the opposite end of the drum screen (No. 7). To prevent clogging of the screen bars, the drum screen is fitted with a brush (No. 8). Furthermore, the drum screen is completely encased in splash guards (No.9) to improve the safety requirement. The prototype of the drum screen with steel structure was constructed as shown in Figure $2 b$.

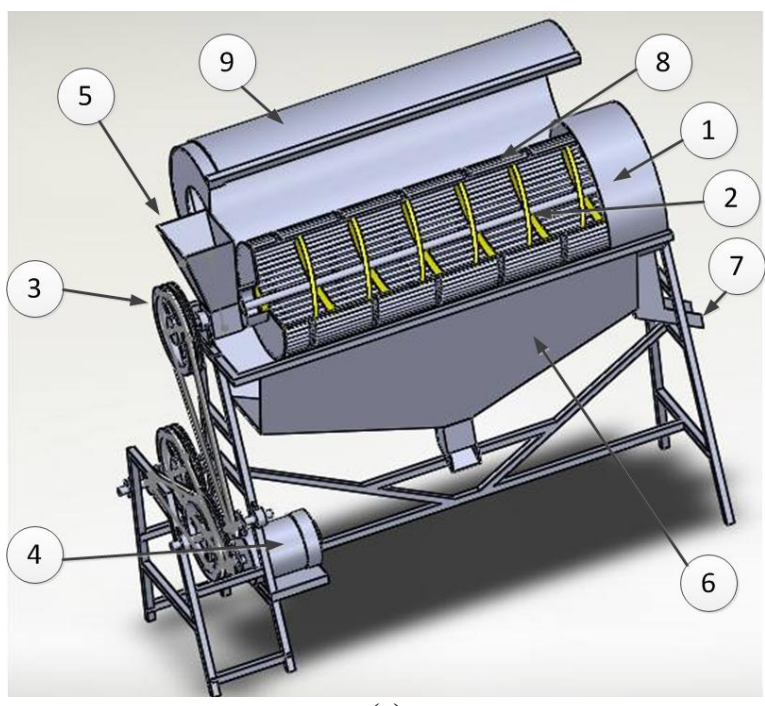

(a)

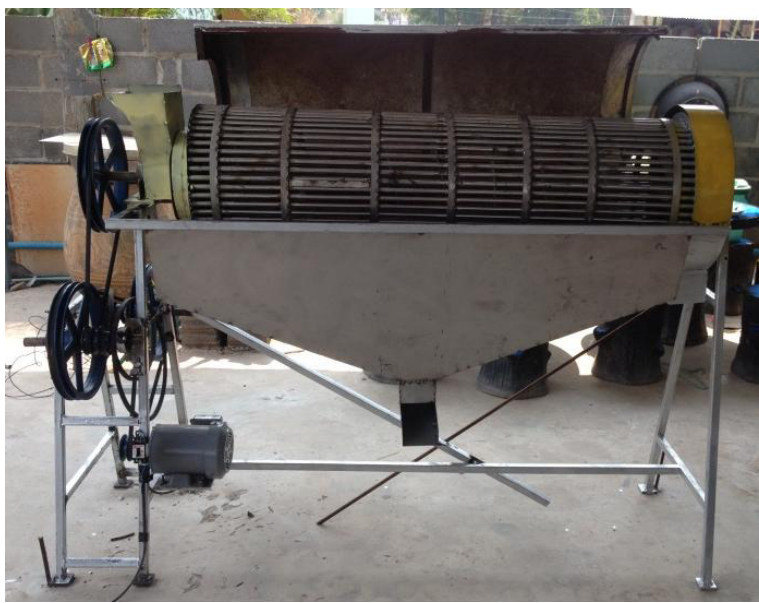

(b)

Figure 2. A drum screen with openings along the drum's rotating direction: (a) the drum screen designed by using $\mathrm{CAD}$ and (b) the prototype of the drum screen.

\section{Experimental results}

To evaluate the performance of the constructed drum screen, two experiments have been conducted. In the first experiment, three rotational velocities of the drum screen, i.e., $20 \mathrm{rpm}(0.42 \mathrm{~m} / \mathrm{s}), 40 \mathrm{rpm}(0.84 \mathrm{~m} / \mathrm{s})$, and $70 \mathrm{rpm}$ $(1.47 \mathrm{~m} / \mathrm{s})$ and three screw pitch values, i.e., 10, 15, and $20 \mathrm{~cm}$ were tested. The working capacity $(\mathrm{kg} / \mathrm{h})$ and the accuracy percentage were measured and shown in Table 1. In this work, the working capacity is defined by the ratio between the mass of all pupae and time spending for sorting, while the accuracy percentage is the ratio between the number of pupae being correctly separated and the number of all pupae being tested. 
Table 1. Performance evaluation at different rotational velocities and different pitch values.

\begin{tabular}{|l|c|c|c|c|c|c|c|c|c|}
\hline Rotational Velocity & \multicolumn{3}{|c|}{20 rpm (0.42 m/s) } & \multicolumn{3}{|c|}{40 rpm (0.84 m/s) } & \multicolumn{3}{c|}{70 rpm (1.47 m/s) } \\
\hline Pitch (cm) & 10 & 15 & 20 & 10 & 15 & 20 & 10 & 15 & 20 \\
\hline Accuracy (\%) & 94.3 & 93.7 & 91.3 & 92.3 & 92.3 & 91.5 & 76.7 & 74.0 & 73.7 \\
\hline Working Capacity (kg/h) & 8.6 & 9.0 & 9.1 & 9.0 & 9.4 & 9.9 & 10.1 & 10.9 & 11.9 \\
\hline
\end{tabular}

One hundred pupae with different size were bought from an Eri Silkworm farm in Mahasarakham Province, Thailand. They were fed manually into the hopper. The experiment was repeated three times. The results (see Table 1) show different significant between working capacity and accuracy percentage. It can be concluded that the faster the drum screen rotated, the less the accuracy percentage was, but the more the working capacity was obtained. Too high rotational velocity through the screen openings made undersized pupae discharge with the acceptable pupae. However, too low rotational velocity caused excessive accumulation of settled pupae, resulting in low working capacity. For the optimal results, the working capacity of $8.6 \mathrm{~kg} / \mathrm{h}$ and the accuracy percentage of $94.3 \%$ were obtained, when the drum screen was operated at the rotational velocity of 20 rpm and the pitch of $10 \mathrm{~cm}$. Figure 3 shows two groups of the pupae which were separated by the drum screen.

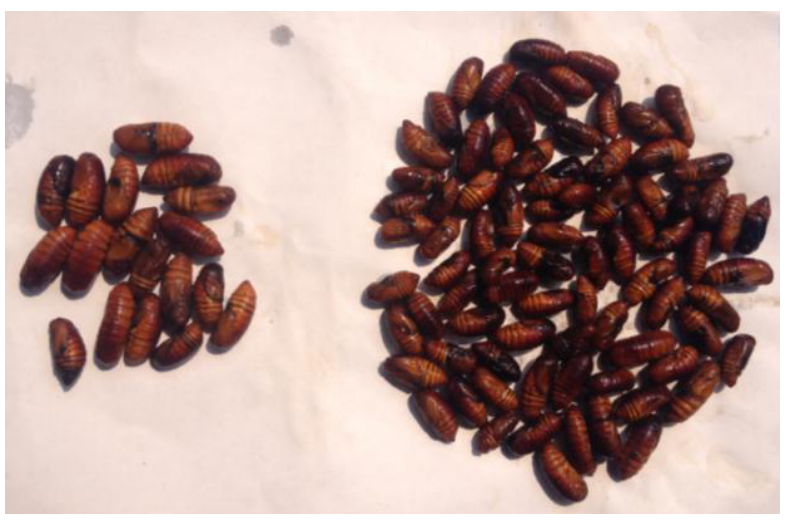

Figure 3. Two groups of pupae after being separated by the drum screen.

Table 2. Performance evaluation between manual screening and our drum screening machine.

\begin{tabular}{|l|c|c|}
\hline & $\begin{array}{c}\text { Screening } \\
\text { Accuracy (\%) }\end{array}$ & $\begin{array}{c}\text { Screening Time } \\
\text { (min) }\end{array}$ \\
\hline $\begin{array}{l}\text { Manual } \\
\text { Screening }\end{array}$ & 90.00 & 12.00 \\
\hline $\begin{array}{l}\text { Machine } \\
\text { Screening }\end{array}$ & 93.75 & 5.25 \\
\hline
\end{tabular}

In the last experiment, working capacity $(\mathrm{kg} / \mathrm{h})$ of the machine was compared to that of manual sieve screening. One kilogram of pupae was screened at the rotational velocity of $20 \mathrm{rpm}$ and the pitch of $10 \mathrm{~cm}$. As seen in Table 2, our drum screen helps to reduce operating time and to increase product quality, while allowing rapid and large volume screening.

\section{Conclusions}

In this paper, a drum screen was developed to separate pupae into two groups, i.e., undersized pupae and acceptable pupae. It consisted of an internal spiral screw which was used to transport pupae from the hopper feeder through screening bars of the drum screen. The pupae whose diameter was less than $9.5 \mathrm{~mm}$ were considered undersized pupae and they were undesirable.

As shown in the experimental results, the optimal rotational velocity of the drum screen was $20 \mathrm{rpm}$ and the optimal value of the screw pitch was $10 \mathrm{~cm}$. These settings gave us the working capacity of $8.6 \mathrm{~kg} / \mathrm{h}$ and the accuracy percentage of $94.3 \%$. Apparently, the drum screen developed in this paper can be used to replace human operators in order to increase consistency, speed, and accuracy. To improve its performance, the hopper control and screening into more than two groups will be our future research work.

\section{Acknowledgements}

The authors would like to thank Mahasarakham University for financial support (Silk Grant) under the fiscal year 2014 national budget and Pongpet Farm for supporting pupa samples. The authors also gratefully acknowledge the financial support from Faculty of Engineering, Mahasarakham University and from Mahasarakham University Development Fund for conference participation.

\section{References}

1. P.A. Priyadarshini, H.M. Revanasiddaiah, Int. J. Curr. Microbiol. Appl. Sci., 2, 215-220 (2013)

2. C. Srikaew, S. Songsermpong, Proceedings of the 50th Kasetsart Annual Conference, 234-243 (2012)

3. D. Londhe, S. Nalawade, G. Pawar, V. Atkari, S. Wandkar, Agri. Eng. Int.: CIGR J., 15, 217 - 230 (2013)

4. G.P. Moreda, J. Ortiz-Cañavatea, F.J. García-Ramos, M. Ruiz-Altisent, J. Food Eng., 92 119-136 (2009)

5. B. Ghanbarian, N. Kolchin, S. Hasan Beigi, R. Ebrahimi, J. Food Proc. Eng., 33, 1148-1158 (2010) 
6. H. Golpira, H. Golpira, Proceedings of the 2012 Int. Conf. on Advanced Mechatronic Systems, 729 - 732 (2012)

7. G. Gamea, M. Aboamera, M. Ahmed, Australian J. Agr. Eng., 2, $74-81$ (2011)

8. W. Kopral, W. Pocwiardowski, M. Domoradzki, J. Kaniewska, CHEMIK, 65, 359-364 (2011)
9. K. Treeamnuk, S. Pathaveerat, A. Terdwongworakul, C. Bupata, Biosyst. Eng., 107, 140-148 (2010)

10. B. Jarimopas, D. Rachanukroa, P. Chen, Proceedings of the 7th International agricultural Engineering Conference, 28-30 (2002)

11. B. Jarimopas, S. Toomsaengtong, C. Inprasit, J. Food Eng., 79, 745-751 (2007) 